\title{
Video otoscopy as a diagnostic tool for canine otoacariasis
}

\author{
Video otoscopia como técnica diagnóstica para otoacaríase canina
}

Clarissa Pimentel de Souza ${ }^{1 *}$; Guilherme Gomes Verocai²; Margareth Balbi ${ }^{3}$; Fabio Barbour Scott ${ }^{1}$

\begin{abstract}
${ }^{1}$ Laboratório de Quimioterapia Experimental em Parasitologia Veterinária, Departamento de Parasitologia Animal, Instituto de Veterinária, Universidade Federal Rural do Rio de Janeiro - UFRRJ, Seropédica, RJ, Brasil

${ }^{2}$ Department of Ecosystem and Public Health, Faculty of Veterinary Medicine, University of Calgary, Calgary AB, Canada ${ }^{3}$ Universidade Estácio de Sá, Campus Vargem Pequena, Rio de Janeiro, RJ, Brasil
\end{abstract}

Received July 2, 2013

Accepted July 17, 2013

\begin{abstract}
Canine otoacariasis, or otodectic mange, is a common parasitic disorder of dogs' ear canals caused by the mite Otodectes cynotis. Infestation can be detected through diverse protocols of varying sensitivity. We evaluated the use of video otoscopy in comparison with conventional otoscopy and cerumen examination under a microscope for diagnosing O. cynotis in dogs. Thirty-five dogs were evaluated bilaterally for the presence of ear mites, using a veterinary otoscope (Gowlands), a video otoscope (Welch Allyn') and the gold-standard technique of examination of swab-collected cerumen under a microscope. Each ear was considered to represent one sample, and 69 ears were examined, since one dog presented with one completely stenotic ear canal. Ear mites were diagnosed in 59.42\% (41/69) through video otoscopy. The same 41 infested ear canals were detected by means of cerumen examination under a microscope, whereas conventional otoscopy was able to diagnose mites in only $39.13 \%(27 / 69)$. This difference was statistically significant $(\mathrm{p}<0.001)$. Video otoscopy proved to be superior to conventional otoscopy, and equivalent to the gold standard for detection of $O$. cynotis in canine ear canals, and should be recommended for controlled trials on drug efficacy for treatment of canine otoacariasis.
\end{abstract}

Keywords: Diagnosis, Otodectes cynotis, ear mites, video otoscopy.

\section{Resumo}

A sarna otodécica ou otoacaríase canina é uma doença parasitária comum em cães causada pelo ácaro Otodectes cynotis. A infestação no conduto auditivo dos animais pode ser diagnosticada através de diversos protocolos com diferentes sensibilidades. Avaliamos o uso da video otoscopia comparada à otoscopia convencional e à observação do cerumem sob microcópio, no diagnóstico de $O$. cynotis em cáes. Trinta e cinco cães foram avaliados bilateralmente para a presença de ácaros através do uso de um otoscópio veterinário (Gowlands"), um vídeo otoscópio (Welch Allyn *) e pela técnica padrão, que é o exame microscópico do cerumem coletado por um "swab". Cada orelha foi considerada uma unidade, sendo que foram examinadas 69 orelhas, pois um cáo apresentou o conduto auditivo completamente estenosado. Os ácaros foram detectados pela video otoscopia em 59.42\% (41/69) dos condutos. Os mesmos 41 infestados foram diagnosticados através do exame do cerumem sob microscopia óptica, enquanto a otoscopia convencional identificou os parasitos em apenas 39.13\% (27/69) das orelhas. A diferença foi estatisticamente significativa ( $<<0,001)$. A video otoscopia provou ser superior a otoscopia convencional para o diagnóstico do ácaro O. cynotis nos condutos auditivos de cáes e deve ser recomendada para ensaios controlados de eficácia de medicamentos para o tratamento da otocaríase canina.

Palavras-chave: Diagnóstico, Otodectes cynotis, ácaros de orelha, vídeo otoscopia.

Otoacariasis, or otodectic mange, is a common parasitic otopathy caused by the psoroptid mite Otodectes cynotis (Hering, 1838), which inhabits the ear canals of different carnivore species, especially dogs and cats. This parasite is very active and contagious, and spends its entire life cycle inside the host's ear

\footnotetext{
*Corresponding author: Clarissa Pimentel de Souza

Universidade Federal Rural do Rio de Janeiro - UFRRJ, BR 465, Km 7 PSA,

CEP 23890-000, Seropédica, RJ, Brasil

e-mail: clarissaps@globo.com
}

canal (SWEATMAN, 1958). Infested animals show discomfort and intense itching, and most commonly develop otitis externa characterized by vertical and horizontal canal erythema and a dark brown, ceruminous otic exudate (CURTIS, 2004).

Canine otoacariasis is usually diagnosed by combining the animal's history and physical examination. This may include: 1) conventional otoscopy, through which parasite movements inside the ear canal can be observed by means of a magnifier; 2) a roll smear of ceruminous exudate, collected using a swab 
or ear curette and examined under an optical microscope; or 3) examination of ear-flush material under a stereomicroscope (MANSFIELD, 1988; GOTTHELF, 2004).

Examination of swab-collected cerumen is considered to be the gold-standard diagnostic technique, but it requires use of a microscope for it to be applied (SOUZA et al., 2004). However, use of swab collection is not recommended in controlled trials testing the efficacy of miticidal drugs. This is because this technique relies on active removal of mites and their eggs along with the cerumen and could bias the results, both in treated and in untreated groups. Instead, otoscopy or video otoscopy should be the preferred reference diagnostic method for $O$. cynotis in controlled drug trials, given that these methods hardly remove any cerumen from the ear canals.

Conventional otoscopy is commonly preferred in general practice. This diagnostic tool does not remove exudates from the ear canal and therefore has been used as a diagnostic tool in studies on drug efficacy against O. cynotis in dogs (SOUZA et al., 2006a, b).

Video otoscopy has emerged as a practical and effective tool for diagnosing and managing otitis externa and media, since it has several advantages over conventional otoscopy (ANGUS; CAMPBELL, 2001). The superior optics of the video otoscope provide a high degree of magnification, thus enabling better viewing and detailed resolution of the ear canal and tympanic membrane. The magnified image on a monitor is generally considered to be far superior to the view obtained through a handheld otoscope (COLE, 2004; MILLER, 2013). To our knowledge, there are no studies in the literature with regard to use of video otoscopy as a diagnostic tool for parasitic disorders of the ear tract of dogs.

The objective of this study was to compare video otoscopy with conventional otoscopy and with the gold standard technique, in order to validate it as a diagnostic tool for canine otoacariasis.

Thirty-five dogs of both sexes and different ages that did not present any ear disorders were examined. Thirty of them were Beagle dogs from a kennel maintained in the Department of Animal Parasitology, Universidade Federal Rural do Rio de Janeiro. The other five dogs included: one Pit Bull, one Labrador retriever, one Teckel and two mixed-breed dogs that had been admitted to the Clinic School of Veterinary, Universidade Estácio de Sá. The animals were initially examined bilaterally by a qualified observer for the presence of $O$. cynotis mites through video otoscopy using a video otoscope (Welch Allyn - Videopath Veterinary Imaging System). Then, all the animals were examined through conventional otoscopy with the aid of an otoscope with veterinary cones (Gowlands'), by a second trained blinded observer. The otoscope cone was changed after examining each ear when conventional otoscopy was performed. Also, the video otoscope was wiped clean between each ear examination, using gauze moistened with isopropyl alcohol.

In order to visually assess the ear canals, the dogs were positioned seated on the examination room table and were evaluated by the observer, who stood laterally to the animals' bodies. The observer evaluated each ear canal for 30 seconds: 15 seconds with each equipment. The criterion for diagnosing infestation was observation of moving mites. No chemical containment was necessary for performing any of the abovementioned procedures.
Afterwards, the gold standard technique was performed by a third blinded person. A small amount of cerumen was collected using a cotton swab from each ear canal of all the dogs and was examined as a rolled smear under a microscope, to confirm the infestation.

Each ear canal was considered to be one sample. Sixty-nine ears were evaluated, since one dog presented one completely stenotic ear canal.

The validity and reproducibility of video otoscopy, in comparison with the gold standard technique, were evaluated as described by Pereira (2002).

The chi-square and Fisher's exact tests were used to determine whether there was any statistically significant difference between video otoscopy and otoscopy.

All the dogs enrolled in the study that tested positive for ear mites were naturally infested. This study was conducted in compliance with the principals of good clinical practice.

Among the 69 ears examined, O. cynotis mites were diagnosed in $59.42 \%$ (41/69) through video otoscopy. The same 41 infested ear canals were detected by the cerumen examination under the microscope (Table 1, Figure 1).

Since the results achieved through video otoscopy were the same as the results obtained through the gold standard test, the techniques were equivalent. Therefore, the sensitivity and specificity of video otoscopy were $100 \%$, as well as the positive predictive value and negative predictive value. The reproducibility, determined through the kappa coefficient of agreement, between the two techniques was $\mathrm{k}=1$, i.e. it was considered perfect.

Table 1. Number of ear canals positive or negative for presence of the ear mite Otodectes cynotis through video otoscopy and the rolled smear from swab-collected cerumen examined under a microscope.

\begin{tabular}{lccc}
\hline \multirow{2}{*}{$\begin{array}{c}\text { Video } \\
\text { otoscopy }\end{array}$} & \multicolumn{3}{c}{ Examination of swab-collected cerumen } \\
\cline { 2 - 4 } Positive & Negative & Total \\
\hline Positive & 41 & 0 & 41 \\
Negative & 0 & 28 & 28 \\
Total & 41 & 28 & 69 \\
\hline
\end{tabular}

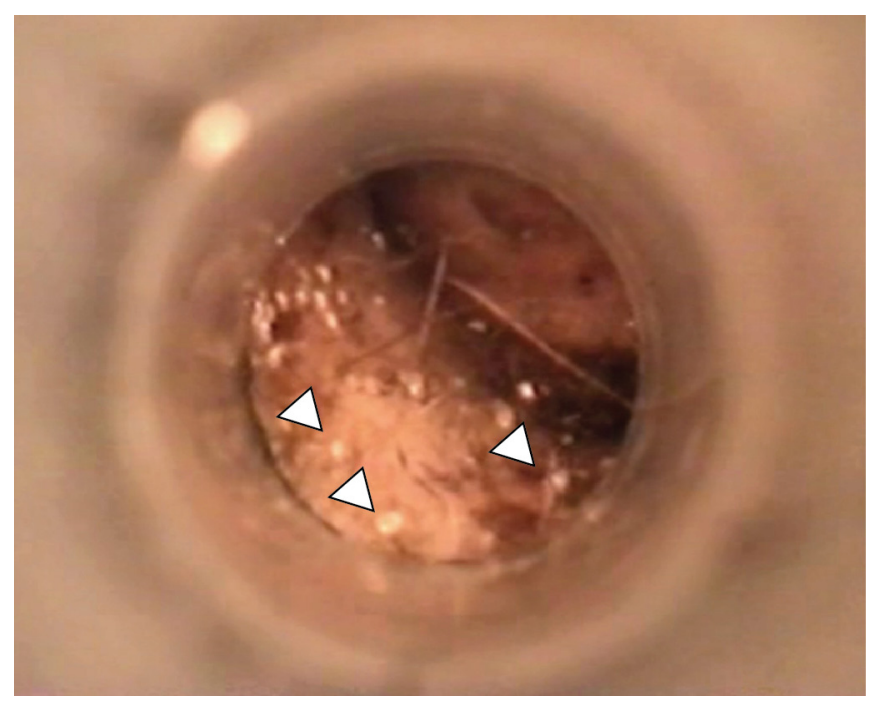

Figure 1. Observation of Otodectes cynotis mites (arrows) inside a dog ear canal through video otoscopy. 
Table 2. Number of ear canals positive or negative for presence of the ear mite Otodectes cynotis through video otoscopy and conventional otoscopy.

\begin{tabular}{lccc}
\hline \multicolumn{1}{c}{$\begin{array}{c}\text { Video } \\
\text { otoscopy }\end{array}$} & \multicolumn{3}{c}{ Conventional otoscopy } \\
\cline { 2 - 4 } & Positive & Negative & Total \\
\hline Positive & 27 & 14 & 41 \\
Negative & 0 & 28 & 28 \\
Total & 27 & 42 & 69 \\
\hline
\end{tabular}

On the other hand, conventional otoscopy was able to detect O. cynotis in only $39.13 \%(27 / 69)$. Thus, mites were observed in 14 ears $(20.29 \%)$ solely by means of video otoscopy, thereby showing its superiority $(\mathrm{p}<0.001)$ for diagnosing otoacariasis in naturally infested dogs. Table 2 shows these results.

Conventional otoscopy is a practical technique that saves a considerable amount of time during examination, but it may not be sufficient in certain cases (COLE, 2004; GRIFFIN, 2006). Some authors have demonstrated that otoscopy has high specificity, but low sensitivity for diagnosing canine otoacariasis, in comparison with examination of rolled smears from cerumen collection (SOUZA et al., 2004).

Our results confirm that conventional otoscopy is also inferior to video otoscopy. The superiority of video otoscopy arises because this technique involves inserting a very small camera into the ear, so that the ear canal appears as a clear, detailed, real-time image on a video monitor, in which mite movement can be clearly seen. The intense light source brightly illuminates the ear and aids in viewing the structures in the ear canal. (COLE, 2004; GRIFFIN, 2006).

In conclusion, video otoscopy was proven to be superior to conventional otoscopy for detection of $O$. cynotis mites in canine ear canals. It should be recommended for trials on drug efficacy for treatment of canine otoacariasis, since the gold standard diagnostic test is not indicated for such purposes.

\section{Acknowledgements}

We gratefully thank Mr. Kenneth Hampton for proof-reading the manuscript prior to submission.

\section{References}

Angus JC, Campbell KL. Uses and indications for video-otoscopy in small animal practice. Vet Clin North Am Small Anim Pract 2001; 31(4): 809-828. PMid:11487956.

Cole LK. Otoscopic evaluation of the ear canal. Vet Clin North Am Small Anim Pract 2004; 34(2): 397-410. PMid:15062615. http://dx.doi. org/10.1016/j.cvsm.2003.10.004

Curtis CF. Current trends in the treatment of Sarcoptes, Cheyletiella and Otodectes mite infestations in dogs and cats. Vet Dermatol 2004; 15(2): 108-114. PMid:15030559. http://dx.doi.org/10.1111/j.13653164.2004.00362.x

Gotthelf LN. Small Animal Ear Diseases: an illustrated guide. 2nd ed. Philadelphia: W. B. Saunders; 2004. PMid:15062620.

Griffin CE. Otitis techniques to improve practice. Clin Tech Small Anim Pract 2006; 21(3): 96-105. PMid:16933476. http://dx.doi. org/10.1053/j.ctsap.2006.05.002

Mansfield PD. Preventive ear care for dogs and cats. Vet Clin North Am Small Anim Pract 1988; 18(4): 845-858. PMid:3264959.

Miller WH, Griffin CE, Campbell KL. Muller and Kirk's Small Animal Dermatology. 7th ed. St. Louis: Elsevier; 2013.

Pereira MG. Epidemiologia Teórica e Prática. Rio de Janeiro: Guanabara Koogan; 2002.

Souza CP, Scott FB, Pereira MJS. Validity and reprodutibility of otoscopy and pinnal pedal reflex on the diagnostic of Otodectes cynotis infestation in dogs. Rev Bras Parasitol Vet 2004: 13(3): 111-114.

Souza CP, Correia TR, Melo RMPS, Verocai GG, Castro DS, Cavalcanti $\mathrm{MCH}$, et al. Eficácia acaricida do tiabendazol sobre Otodectes cynotis (Hering, 1838) em cáes. Rev Bras Parasitol Vet 2006a; 15(4): 143-146. PMid:17196116.

Souza CP, Verocai GG, Correia TR, Melo RMPS, Cavalcanti MCH, Scott FB. Eficácia do diazinon em uma formulaçáo de uso otológico no tratamento da sarna otodécica em cães. Parasitol Latinoam 2006b; 61(3-4): 176-178

Sweatman GK. Biology of Otodectes cynotis, the ear canker mite of carnivores. Can JZool 1958; 36(6): 849-862. http://dx.doi.org/10.1139/ z58-072 